\title{
PEMBUATAN DAN UJI MUTU TEPUNG UMBI PORANG (Amorphophallus Oncophyllus Prain) DI KECAMATAN NGRAYUN
}

\author{
Tatik Handayani ${ }^{1}$, Yaya Sulthon $\mathrm{Aziz}^{2}$, Depit Herlinasari ${ }^{3}$ \\ Akafarma Sunan Giri Ponorogo, Jl. Batoro Katong 32 Ponorogo \\ Email: ${ }^{1)}$ zulfafarma@gmail.com, ${ }^{2)}$ aptgolong@gmail.com, \\ ${ }^{3)}$ dekdepitherlinasari@ gmail.com
}

\begin{abstract}
ABSTRAK
Latar belakang: Umbi porang di Kecamatan Ngrayun berpotensi dijadikan tepung yang dapat menjadi inovasi pangan serta meningkatkan ekonomi masyarakat Ngrayun. Tujuan: Untuk mengetahui kadar kalsium oksalat dan hasil pemutihan (bleaching) tepung umbi porang serta hasil uji mutu tepung umbi porang sesuai dengan SNI 7939:2013. Populasi dalam penelitian yaitu tepung yang terbuat dari umbi porang Kecamatan Ngrayun yang sudah direduksi kalsium oksalatnya dan melewati proses pemutihan. Sampel dalam penelitian yaitu tepung umbi porang dalam sekali produksi yang diambil secara acak. Metode: dilakukan uji mutu SNI 7939:2013 terbatas serpih porang yang meliputi uji kadar air, uji kadar glukomanan, dan uji kadar abu. Dilakukan pula uji reduksi kalsium oksalat dan uji derajat putih. Hasil: pengujian mutu sesuai SNI 7939:2013 bahwa tepung umbi porang memenuhi persyaratan kecuali kadar abu. Hasil uji kadar air 12,965\%, kadar glukomanan 50,103\%, kadar abu 90,733\%, kadar kalsium oksalat setelah direduksi 0,00053 mg, dan derajat putih 315. Simpulan dan Saran: Tepung umbi porang tersebut memenuhi persyaratan kecuali kadar abu, sehingga tepung belum dapat untuk dikonsumsi dan perlu pengolahan yang lebih baik lagi.
\end{abstract}

Kata Kunci: Tepung, umbi porang, uji mutu

\begin{abstract}
Background: Porang tubers in Ngrayun District have the potential to be used as flour which can be a food innovation and improve the economy of the Ngrayun community. Objective: To determine the level of calcium oxalate and the results of bleaching (bleaching) of porang tuber flour and the results of the quality test of porang tuber flour according to SNI 7939: 2013. The population in this study was flour made from porang tubers in Ngrayun District which had reduced calcium oxalate and went through a bleaching process. The sample in this research is porang tuber flour in one product which is taken randomly. Methods: conducted a quality test of SNI 7939: 2013 limited to porang flakes which includes water content test, glucomannan content test, and ash content test. Calcium oxalate reduction test and whiteness test were also performed. Result: quality test according to SNI 7939: 2013 that porang tuber flour meets the requirements except for ash content. The results of the test of moisture content $12.965 \%$, glucomannan content $50.103 \%$, ash content $90.733 \%$, calcium oxalate content after reduction of $0.00053 \mathrm{mg}$, and 315 degrees of whiteness. Conclusion and Suggestion: The porang tuber flour meets the requirements except for the ash content, so the flour cannot be consumed and need better processing.
\end{abstract}

Keywords: Flour, porang tubers, quality test

\section{PENDAHULUAN}

Tanaman yang mudah tumbuh di Kecamatan Ngrayun salah satunya adalah umbi-umbian. Tanaman ini mudah tumbuh di dataran tinggi dan tidak memerlukan kondisi tanah yang spesifik (Taufiqullah, 2019). Adapun umbi yang menjadi primadona dan tengah di gencar-gencarkan penanamannya di Kecamatan Ngrayun saat ini adalah umbi porang. Umbi satu ini memiliki banyak 


\section{Jurnal MEDFARM: Farmasi dan Kesehatan}

Vol. 9, No.1, Januari 2020, hal 13-21

e-ISSN : 2715-9957

fungsi dan manfaat serta termasuk dalam tanaman obat. Tanaman porang mempunyai peluang besar untuk diekspor, sehingga perlu untuk dikembangkan. Seperti yang dikutip dari Catatan Badan Karantina Pertanian bahwa ekspor porang pada tahun 2018 tercatat sebanyak 254 ton, dengan nilai ekspor mencapai Rp. 11, 31 miliar ke negara Jepang, Cina, Australia, Vietnam dan lain sebagainya (Sutiyawan, 2019).

Umbi porang memiliki kandungan glukomanan sebesar 45-65\%. Glukomanan merupkakan sebuah zat dalam bentuk gula kompleks dan serat larut yang sumber tertinggi di Indonesia sendiri, disebut-sebut berasal dari tanaman Porang. Dalam penggunaan dibidang makanan, glukomanan mempunyai daya serap air yang sangat baik serta merupakan salah satu serat makanan yang paling kental, dan memberikan efek gel, hingga saat ini digunakan untuk pengikatan, penebalan, pengganti pengawet, dan pengganti lemak (Team, honesdoct editorial. 2020). Glukomanan juga banyak digunakan dalam industri farmasi karena baik bagi kesehatan (Palupi, 2009). Selain itu sebagai bahan lem, bahan edible film, dan masih banyak lagi kegunaannya (Widari dan Rasmito, 2018). Selain kandungan glukomanan yang sarat akan manfaat, umbi porang juga mengandung zat kimia bernama kalsium oksalat yang mejadi kendala dalam pengolahannya. Senyawa ini berupa kristal berbentuk jarum tajam yang menanamkan diri dalam jaringan sehingga dapat menyebabkan sakit luar biasa. Oksalat bersama dengan mineral kalsium dalam tubuh manusia dapat membentuk senyawa yang tidak larut sehingga tidak dapat diserap tubuh. Kalsium oksalat sebagai penyebab sekitar 80 persen penyakit batu ginjal pada orang dewasa (Candra, A. 2011). Kalsium oksalat yang terkandung dalam umbi porang ini menyebabkan rasa gatal dan ketika diekstraksi akan mempengaruhi kualitas tepung glukomanan, sehingga perlu dilakukan penurunan kadar kalsium oksalat (Nurenik, 2016). Menurut Susilawati dan Lestari (2015), kalsium oksalat dapat dihilangkan mnenggunakan metode pencucian dengan air yang banyak atau dengan cara perebusan terus-menerus hingga mendapatkan hasil optimal.

Penelitian mengenai reduksi kalsium oksalat pada umbi porang sebelumnya yaitu kondisi terbaik diperoleh pada perlakuan perebusan pada suhu $80^{\circ} \mathrm{C}$ didalam larutan $\mathrm{NaCl} 8 \%$ selama 25 menit, dimana persentase reduksinya mencapai $90,9 \%$ atau dengan kata lain kadar oksalat yang tertinggal didalam umbi porang adalah 0,55\%. (Widari dan Rasmito, 2018). Metode perendaman menggunakan $\mathrm{NaCl}$ juga dapat mereduksi kadar kalsium oksalat umbi porang, yaitu dengan nilai persentase reduksi tertinggi yaitu dengan $\mathrm{NaCl} 15 \%$ menghasilkan peresentase reduksi sebesar 91,6\%. Hal ini menunjukkan bahwa semakin banyak partikel $\mathrm{Na}^{+}$dan $\mathrm{Cl}^{-}$yang terdapat didalam larutan maka semakin banyak pula ikatan yang terjadi yang menghasilkan kalsium oksalat larut dalam air sehingga kadar kalsium oksalat dalam sampel dapat tereduksi. Dalam bentuk makanan yang dapat dikonsumsi, kandungan kalsium oksalat yang diizinkan sebesar 71 miligram/100 gram. Dalam proses pengolahannya, umbi porang rentan dengan reaksi browning atau pecoklatan sehingga dapat menurunkan kualitas olahan umbi porang. Pada penelitian Pasaribu et al tahun 2015, penambahan 


\section{Jurnal MEDFARM: Farmasi dan Kesehatan}

Vol. 9, No.1, Januari 2020, hal 13-21

e-ISSN : 2715-9957

natrium bisulfit $1 \%$ pada tepung porang selama 10 menit dapat meningkatkan derajat putih tepung umbi porang sebesar 67,89\% (Ulfa dan Nafi'ah, 2018).

Penelitian ini bertujuan untuk mengetahui kadar kalsium oksalat pada tepung umbi porang setelah reduksi, mengetahui hasil pemutihan (bleaching) tepung umbi porang yang direndam menggunakan natrium bisulfit $0,02 \%$ selama 10 menit, serta mengetahui mutu tepung umbi porang apakah sesuai dengan SNI 7939:2013 terbatas serpih porang meliputi kadar air, kadar glukomanan, dan kadar abu.

\section{METODOLOGI PENELITIAN}

Penelitian ini dilaksanakan di Laboratorium Akafarma Sunan Giri Ponorogo pada bulan JuliAgustus 2020. Sampel dalam penelitian yaitu tepung umbi porang dalam sekali produksi. menggunakan teknik pengumpulan data Sample Random Sampling. Sampel kemudian dilakukan uji mutu SNI 7939:2013 terbatas serpih porang yang meliputi uji kadar air, uji kadar glukomanan, dan uji kadar abu. Dilakukan pula uji reduksi kalsium oksalat dan uji derajat putih.

\section{ALAT DAN BAHAN}

Alat timbang, oven, ayakan mesh 100, desikator, krus porselen, alat titrasi, penangas listrik, alat penepung stainless, pipet volume, pipet tetes, pipet ukur, tanur, erlenmeyer, beaker glass, labu takar, batu didih, kertas saring, lemari es, penyaring vakum, kamera DSLR, dan program paint windows 7.

Bahan-bahan yang digunakan antara lain: Umbi porang mentah, sampel tepung umbi porang, natrium bisulfit $0,02 \%, \mathrm{NaCl} 8 \%$, larutan $\mathrm{KMnO}_{4} 0,01 \mathrm{~N}$, larutan $\mathrm{H}_{2} \mathrm{C}_{2} \mathrm{O}_{4} \cdot 2 \mathrm{H}_{2} \mathrm{O} \quad 0,01 \mathrm{~N}, \mathrm{NaOH}$ $30 \%, \mathrm{H}_{2} \mathrm{SO}_{4} 2 \mathrm{~N}$, Aquadest sebagai pelarut, $\mathrm{HCl}$ (bd 1, 025), fenolftalein, $\mathrm{NaOH} 10 \%$, asam asetat pekat, fenilhidrazin, aseton.

\section{Pembuatan Tepung Umbi Porang}

Umbi porang dipilih yang tua dan segar, kemudian ditimbang sebanyak $5 \mathrm{~kg}$. Umbi porang dikupas kulitnya, dicuci dengan air, diiris sehingga berbentuk chip dengan ketebalan 2-3 mm. Chip umbi porang tersebut kemudian direbus menggunakan larutan $\mathrm{NaCl} 15 \%$ pada suhu $80^{\circ} \mathrm{C}$ selama 25 menit. Chip umbi porang hasil rebusan dicuci dengan air lalu ditiriskan kemudian dilakukan perendaman dengan natrium bisulfit $0,02 \%$ selama 10 menit. Dicuci dan ditiriskan lalu dikeringkan dibawah sinar matahari dari pukul 08.00 WIB sampai pukul 15.30 WIB atau samapai chip kering ditandai dengan bunyi " $k r e k$ ". Pada malam hari, umbi porang tersebut diangin-anginkan diatas tikar penjemur didalam ruangan. Setelah penjemuran selama 7 hari, chip yang sudah kering tersebut di analisis kembali kadar kalsium oksalatnya dengan metode titrasi permanganometri. Nyalakan mesin penepung stainless dan siapkan wadah penampungan untuk tepung umbi porang. Masukkan chip umbi porang yang sudah ditimbang ke dalam mesin penepung melalui corong input. Matikan mesin 


\section{Jurnal MEDFARM: Farmasi dan Kesehatan}

Vol. 9, No.1, Januari 2020, hal 13-21

e-ISSN : 2715-9957

jika proses penggilingan sudah selesai dan bersihkan mesin. Tepung hasil penggilingan diayak menggunakan ayakan.

\section{Analisis Kadar Kalsium Oksalat Tepung Umbi Porang dengan Metode Titrasi Permanganometri}

Menimbang 56 gram sampel tepung umbi porang, kemudian dimasukkan kedalam $250 \mathrm{ml}$ beaker glass. Menambahkan aquades $100 \mathrm{ml}$. Memanaskan atau mendidihkan selama 15 menit menggunakan hot plate sambil diaduk. Didinginkan lalu didiamkan dan disimpan selama satu malam. Disaring dengan kertas saring whatman no. 30, lalu dimasukkan ke dalam labu ukur $250 \mathrm{~mL}$, kemudian ditrambahkan aquades sampai tanda tera. Dipipet $25 \mathrm{ml}$ filtrat tersebut kedalam beaker glass $50 \mathrm{ml}$, lalu tambahkan $\mathrm{NaOH} 30 \%$, teteskan sampai $\mathrm{pH}$ 7-8. Ditambahkan larutan $\mathrm{CaCl}_{2}$ sebanyak $5 \mathrm{ml}$, dikocok, lalu dibilas pengaduk dengan aquades, disimpan satu malam. Diputar selama 10 menit pada $2000 \mathrm{rpm}$, dibuang supernatant hati-hati dengan perlahan-lahan. Endapan (kalsium oksalat) dicuci dengan $20 \mathrm{~mL}$ larutan pencuci (aquades), ulang pencuciannya sebanyak 2 kali, lalu pindahkan kedalam labu erlenmeyer. Dipanaskan di atas hot plate. Dititrasi dengan keadaan panaspanas dengan $0,01 \mathrm{~N}$ kalium permanganat.

\section{Analisis Derajat Putih Tepung Umbi Porang.}

Mengambil foto chip sebelum dan sesudah proses pemutihan. Hasil foto kemudian dikirim ke program paint windows 7 , dan buka file tersebut. Pada menu toolspaint, klik pada tool color picker. Klik pada warna yang ingin diketahui nilai RGBnya. Klik pada menu edit colors, akan muncul window edit colors. Pada window edit colors, dapat dilihat nilai RGBnya.

\section{Uji Kadar Air}

penetapan kadar air dilakukan dengan metode gravimetri atau pengeringan. Analisis kadar air dengan pengeringan, penentuan kadar airnya didasarkan pada penimbangan berat. Ditimbang wadah kosong yang telah dikeringkan $\left(\mathrm{W}_{0}\right)$, diitimbang contoh uji sebanyak 5 gram dan dimasukkan kedalam wadah yang telah diketahui bobotnya $\left(\mathrm{W}_{1}\right)$. Wadah berisis serbuk dioven selama 3 jam pada suhu $\left(105 \pm 3^{\circ} \mathrm{C}\right)$. Wadah berisi serbuk dikekuarkan dan ditempatkan ke dalam desikator hingga dingin dan ditimbang. Contoh uji dioven kembali selama 3 jam pada suhu $\left(105 \pm 3^{\circ} \mathrm{C}\right)$ sampai tercapai bobot konstan $\left(\mathrm{W}_{2}\right)$.

\section{Uji Kadar Glukomanan}

Pengukuran kadar glukomanan pada penelitian ini dilakukan dengan metode phenylhidrazin. Prinsip uji phenylhidrazine adalah berdasakan gugus karbonil dari aldosa dan ketosa yang bereaksi dengan adanya penambahan larutan phenylhidrazine akan membetuk senyawa osazon berwarna 


\section{Jurnal MEDFARM: Farmasi dan Kesehatan}

Vol. 9, No.1, Januari 2020, hal 13-21

e-ISSN : 2715-9957

kuning jingga. Ditimbang contoh uji yang berupa serbuk halus seberat $1 \mathrm{~g}\left(\mathrm{~W}_{0}\right)$, dimasukkan contoh uji ke dalam erlenmeyer $100 \mathrm{~mL}$, ditambahkan $30 \mathrm{~mL} \mathrm{HCl}$ (bd 1,025) dan batu didih. Direfluks selama 3,5 jam kemudian saring menggunakan kertas saring. Dibilas endapan pada kertas saring dengan air mendidih kemudian disaring, lalu dicampurkan kedua filtrate kemudian ditambahkan 3 tetes fenolftalein kemudian dibasakan dengan $\mathrm{NaOH} 10 \%$ sampai warna larutan menjadi merah muda. Asamkan filtrate dengan menggunakan asam asetat pekat sampai larutan menjadi asam. Asamkan larutan sampai menjadi volume yang kecil (sekitar $30 \mathrm{ml}$ sampai dengan $40 \mathrm{ml}$ ) kemudian disaring. Ditambahkan ke dalam larutan tersebut 1,5 $\mathrm{ml}$ fenilhidrazin, 1,5 $\mathrm{ml}$ asam asetat pekat dan $10 \mathrm{~mL}$ air suling. Biarkan larutan sampai mencapai suhu kamar kemudian dimasukkan ke dalam lemari es selama 1 malam. Saring mannose fenilhidrazon yang terbentuk dengan penyaring vakum, kemudian cuci endapan beberapa kali dengan $15 \mathrm{ml}$ air suling. Terakhir dicuci dengan $10 \mathrm{~mL}$ aseton, lalu dikeringkan endapan dengan menggunakan oven dan ditimbang hingga bobot tetap $\left(\mathrm{W}_{1}\right)$.

\section{Uji Kadar Abu}

Pada penelitian ini, kadar abu ditentukan dengan cara kering sebagai berikut: Dipanaskan cawan porselen pada suhu $(625 \pm 5){ }^{\circ} \mathrm{C}$ selama \pm 20 menit dan dimasukkan dalam desikator. Ditimbang cawan porselen $\left(\mathrm{W}_{0}\right)$. Ditimbang dengan teliti (2-3) gram contoh uji yang telah dibuat serbuk dalam cawan porselen $\left(\mathrm{W}_{1}\right)$. Perarang cawan yang berisi contoh uji pada suhu (300-400) ${ }^{\circ} \mathrm{C}$. Dimasukkan cawan beserta contoh uji ke dalam tanur pada suhu (600-700) ${ }^{\circ} \mathrm{C}$ sampai diperoleh abu selama \pm 30 menit. Didinginkan dalam desikator dan timbang sampai bobot tetap $\left(\mathrm{W}_{2}\right)$.

\section{HASIL DAN PEMBAHASAN}

\section{Organoleptik Tepung}

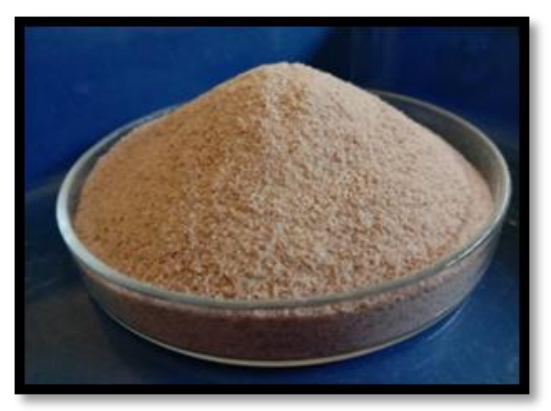

Gambar 1. Tepung Umbi Porang

Sampel tepung umbi porang memiliki warna putih kecoklatan yang berasal dari warna alami umbi porang dengan hasil pemutihan menggunakan natrium bisulfit. Tepung ini memiliki aroma khas dari tepung, berbentuk serbuk, dan memiliki rasa yang gurih sedikit asin karena efek dari proses 


\section{Jurnal MEDFARM: Farmasi dan Kesehatan}

Vol. 9, No.1, Januari 2020, hal 13-21

e-ISSN : 2715-9957

perebusan menggunakan $\mathrm{NaCl}$. Tepung ini memiliki ciri-ciri yang hampir sama dengan tepung pada umumya namun teksturnya sedikit lebih kasar.

Tabel 1. Hasil Uji Organoleptik

\begin{tabular}{cc}
\hline Uji Organoleptik & Hasil Uji Organoleptik \\
\hline Warna & Putih kecoklatan \\
Aroma & aroma khas tepung \\
Bentuk & Serbuk \\
Rasa & Gurih agak asin \\
\hline
\end{tabular}

\section{Kadar Air}

\begin{tabular}{cccccc}
\multicolumn{5}{c}{ Tabel 2. Hasil Uji Kadar Air } \\
\hline $\begin{array}{c}\text { Replikasi } \\
\text { Sampel }\end{array}$ & $\begin{array}{c}\text { Hasil } \\
\text { Kadar Air } \\
(\%)\end{array}$ & $\begin{array}{c}\text { Rata-rata hasil } \\
(\%)\end{array}$ & \multicolumn{2}{c}{ Persyaratan SNI 7939:2013 (\%) } \\
& & & $\begin{array}{c}\text { Mutu } \\
\text { I }\end{array}$ & Mutu II & $\begin{array}{c}\text { Mutu } \\
\text { III }\end{array}$ \\
\hline 1 & 12,957 & 12,965 & $\leq 13$ & $13-<15$ & $15-16$ \\
2 & 12,969 & & & & \\
3 & 12,969 & & &
\end{tabular}

Berdasarkan hasil pengujian kadar air pada tabel 2, nilai kadar air pada sampel tepung umbi porang berturut-turut yaitu $12,957 \%, 12,963 \%, 12,963 \%$ dengan hasil rata-rata $12,965 \%$. Nilai kadar air pada tepung ini memenuhi persyaratan yang telah ditetapkan oleh SNI 7939:2013 mutu III yaitu $15 \%$ - 16\%. Adapun kelebihan mutu tepung ini adalah kadar airnya dapat mencapai standart minimum dalam penelitian bahkan dapat mencapai mutu II dan mutu I yaitu mutu I $\leq 13 \%$ dan mutu II $13 \%$ - < 15\%. Semakin lama proses penjemuran maka kadar air akan semakin kecil. Kadar air yang tinggi menyebabkan mudahnya bakteri maupun jamur tumbuh pada pangan dan juga akan memperpendek masa simpan bahan pangan.

\section{Kadar Glukomanan}

Tabel 3. Hasil Uji Glukomanan

\begin{tabular}{cccccc}
\hline $\begin{array}{c}\text { Replikasi } \\
\text { Sampel }\end{array}$ & $\begin{array}{c}\text { Hasil Kadar } \\
\text { Glukomnan (\%) }\end{array}$ & $\begin{array}{c}\text { Rata-rata } \\
\text { hasil (\%) }\end{array}$ & $\begin{array}{c}\text { Mutu } \\
\text { I }\end{array}$ & $\begin{array}{c}\text { Mutu } \\
\text { II }\end{array}$ & $\begin{array}{c}\text { Mutu } \\
\text { III }\end{array}$ \\
\hline 1 & 47,752 & & & & \\
2 & 52,974 & 50,103 & $>25$ & $20-\leq 25$ & $15<20$ \\
3 & 49,584 & & & & \\
\hline
\end{tabular}

Berdasarkan hasil pengujian kadar glukomanan pada tabel 3 diperoleh nilai data berturut-turut 47,753\%, 52,974\%, 49,584\% sehingga memiliki rata-rata nilai kadar glukomanan sebesar 50,103\%. Persyaratan yang telah ditetapkan oleh SNI 7939:2013 III yaitu 15 - <20, sehingga kadar glukomanan 


\section{Jurnal MEDFARM: Farmasi dan Kesehatan}

Vol. 9, No.1, Januari 2020, hal 13-21

e-ISSN : 2715-9957

sampel memenuhi syarat. Hasil yang diperoleh sangat tinggi dari standar yang ditetapkan dalam mutu III, artinya kadar glukomanan yang terkandung lebih banyak dan mutu lebih baik. Jika dibandingkan dengan mutu I > 25\% dan mutu II 15\%, maka mutu glukomanan layak untuk samapai mutu I.

Penyebab dari tingginya kadar glukomanan adalah kandungan glukomanan yang terkadung lebih banyak disebabkan faktor umur, cara pengolahan, dan lama penyimpanan. Pada saat analisis, tahap pemisahan dengan refluk sangat berpengaruh terhadap endapan glukomanan yang didapatkan, serta proses pengolahan dengan perebusan menggunakan larutan $\mathrm{NaCl}$ dengan suhu panas yaitu $80{ }^{\circ} \mathrm{C}$ menyebaban glukomanan sedikit terlarut dan terbuang bersama larutan $\mathrm{NaCl}$ saat dibilas, sehingga kemungkinan kadar glukomanan murni pada sampel mentah dapat lebih tinggi. Kadar glukomanan yang terdapat pada sampel tersebut tinggi menandakan tingginya mutu tepung tersebut, karena manfaat tepung porang banyak diambil dari kandungan glukomanannya.

\section{Kadar Abu}

Tabel 4. Hasil Uji Kadar Abu

\begin{tabular}{cccccc}
\hline $\begin{array}{c}\text { Replikasi } \\
\text { sampel }\end{array}$ & $\begin{array}{c}\text { Hasil Kadar } \\
\text { Abu (\%) }\end{array}$ & $\begin{array}{c}\text { Rata-rata } \\
\text { hasil } \\
(\%)\end{array}$ & \multicolumn{3}{c}{ Persyaratan SNI 7939-2013 (\%) } \\
Mutu I & Mutu II & Mutu III \\
\hline 1 & 9,250 & & & & \\
2 & 9,190 & 9,261 & $\leq 4$ & $-<5$ & $5-6,5$ \\
3 & 9,345 & & & & \\
\hline
\end{tabular}

Berdasarkan hasil pengujian kadar abu pada tabel 4 diperoleh nilai data berturut-turut 9,250\%, 9,190\%, 9,345\% dan sampel memiliki rata-rata nilai kadar abu sebesar 9,261\%. Nilai kadar abu pada sampel tepung porang ini tidak memenuhi persyaratan yang telah ditetapkan oleh SNI 7939:2013 mutu III yaitu 5\% sampai 6,5\%. Penyebab dari tingginya kadar abu adalah kandungan mineral yang terkadung lebih banyak, pada tahap pendiginan setelah dilakukan pengabuan dalam tanur diduga udara sekitar yang lembab menyebabkan bahan menyerap mineral disekitar desikator, serta pengolahan dengan perebusan menggunakan larutan $\mathrm{NaCl}$ dimana $\mathrm{NaCl}$ merupakan zat anorganik berbentuk garam sehingga didiuga menjadi penyebab tingginya kadar abu. Kadar abu yang tinggi menandakan jika mineral yang terdapat pada sampel tinggi dan mineral yang tinggi pada bahan pangan mengakibatkan sulit untuk dicerna oleh sistem pencernaan.

\section{Kadar Kalsium Oksalat}

\begin{tabular}{cccc}
\hline $\begin{array}{c}\text { Replikasi } \\
\text { Sampel }\end{array}$ & $\begin{array}{c}\text { Hasil Kadar } \\
\text { kalsium oksalat } \\
(\mathrm{mg} / 100 \mathrm{~g}) \\
\text { sebelum reduksi }\end{array}$ & $\begin{array}{c}\text { Hasil Kadar } \\
\text { kalsium oksalat } \\
(\mathrm{mg} / 100 \mathrm{~g}) \text { setelah } \\
\text { reduksi }\end{array}$ & $\begin{array}{c}\text { Persyaratan(Ulfa dan } \\
\text { Nafi'ah:2008) }\end{array}$ \\
\hline 1 & 0,0225 & 0,0009 & $71 \mathrm{mg} / 100 \mathrm{~g}$ \\
\hline
\end{tabular}


Uji Kadar Kalsium Oksalat

Berdasarkan pada tabel 5 sebelum diolah umbi porang di analisis kadar kalsium oksalat awal dan mendapatkan hasil sebesar $0,0225 \mathrm{mg} / 100 \mathrm{~g}$ sedangkan hasil pengujian kadar kalsium oksalat setelah diolah dan menjadi menjadi tepung memiliki rata-rata nilai kadar kalsium oksalat 0,0009 $\mathrm{mg} / 100$ g. Nilai kadar kalsium oksalat pada sampel tepung porang ini memenuhi persyaratan pada penelitian (Ulfa dan Nafi'ah:2008) yang menyebutan bahwa kadar kalsium oksalat maksimal yaitu 71 $\mathrm{mg} / 100 \mathrm{~g}$. Kalsium oksalat yang terkandung dalam umbi porang ini menyebabkan rasa gatal dan ketika diekstraksi akan mempengaruhi kualitas tepung glukomanan, sehingga perlu dilakukan penurunan kadar kalsium oksalat (Nurenik, 2016).

\section{Derajat Putih}

Tabel 6. Hasil Uji Derajat Putih

\begin{tabular}{lccccc}
\hline Sampel & Red & Green & Blue & $\begin{array}{l}\text { Derajat } \\
\text { putih }\end{array}$ & $\begin{array}{l}\text { Derajat } \\
\text { putih } \\
\text { maksimal }\end{array}$ \\
\hline $\begin{array}{l}\text { Sebelum } \\
\text { Pemutihan }\end{array}$ & 113 & 113 & 89 & 315 & \\
$\begin{array}{l}\text { Setelah } \\
\text { pemutihan }\end{array}$ & 173 & 173 & 149 & 495 & 765 \\
\hline
\end{tabular}

Berdasarkan hasil pengujian derajat putih tepung pada tabel 6, sampel tepung umbi porang tanpa pemutihan memiliki nilai derajat putih red 113, green 113, blue 89 sehingga jumlahnya sebesar 315. Nilai derajat putih tepung porang setelah pemutihan yaitu red 173, green 173, blue 149 sehingga jumlahnya sebesar 495. Sedangkan untuk nilai kadar putih maksimal pada aplikasi paint yaitu sebesar 765. Nilai derajat putih pada tepung umbi porang mengalami kenaikan walaupun belum mencapai standar putih maksimal.

Penggunaan natrium bisulfit dengan konsentrasi yang lebih tinggi akan menghasilkan derajat putih yang lebih tinggi dan tentunya akan lebih terlihat menarik. Akan tetapi penggunaan natrium bisulfit sebagai pemutih dalam makanan kadarnya juga harus memperhatikan batas aman agar tidak meracuni tubuh.

\section{KESIMPULAN DAN SARAN}

\section{Kesimpulan}

Uji kadar kalsium oksalat setelah reduksi pada tepung diperoleh hasil 0,0009 mg/100 g yang berarti memenuhi syarat batas aman yang diizinkan sebesar 71 miligram/100 gram. Uji derajat putih pada tepung diperoleh hasil 315 sebelum pemutihan dan 495 setelah pemutihan yang berarti tepung 


\section{Jurnal MEDFARM: Farmasi dan Kesehatan}

Vol. 9, No.1, Januari 2020, hal 13-21

e-ISSN : 2715-9957

mengalami kenaiakan derajat putih. Dari hasil pengujian pada sampel tepung umbi porang pada uji kadar air didapat nilai kadar 12,965\%, uji kadar glukomanan didapat nilai kadar 50,103\% yang berarti memenuhi persyaratan SNI 7939:2013, kadar abu didapa nilai kadar 9,261\% yang berarti tidak memenuhi persyaratan mutu tersebut.

\section{Saran}

Diharapkan masyarakat dapat mengolah umbi porang sebagai salah satu inovasi pangan khususnya untuk dijadikan tepung. Diharapkan dapat dilakukan pengujian parameter mutu yang khusus tentang SNI tepung porang sehingga dapat diperoleh produk tepung umbi porang dengan kualitas yang lebih baik. Tepung umbi porang produksi ini belum dapat dimanfaarkan untuk bahan pangan alternatif karena diperoleh kadar abu yang masih tinggi.

\section{DAFTAR PUSTAKA}

Badan Standarisasi Nasional.2013. Serpih Porang .SNI No. 7939:2013. Badan Standarisasi Nasional. Jakarta.

Candra, Asep. 2011. Efek Oksalat Bagi Kesehatan. Kompas.com

Nurenik.et al. 2016. Perubahan Sifat Fisik Dan Penurunan Kadar Kalsium Oksalat Pada Tepung Porang (Amorphophallus Oncophyllus) Dengan Varisasi Penyosohan Dan Penghembusan Udara Serta Perendaman Etanol.Jurnal Teknik pertanian, (1), (Online), (http://etd.repository.ugm.ac.id/penelitian/detail/101992), diaksees 10 Januari 2020.

Palupi, N. 2019. Tanaman Porang. https://www.tribunnewswiki.com/2019/10/30/ tanaman-porang, diakses Senin 23 Desember 2019.

Susilawati dan Lestari. 2015. Uji organoleptik mi basah berbahan dasar tepung talas beneng (Xantoshoma undipes) untuk meningkatkan nilai tambah bahan pangan lokal Banten. Jurnal Teknik Kimia, 1 (942), (Online), (http://www.smujo.id), diakses pada 11 Januari 2020.

Sutiawan, iwan. 2019. Kementan Kembangkan Budidaya Umbi Porang untuk Ekspor, (Online), (https://www.gatra.com/detail/news/443601/ekonomi/kementan kembangkan-budidaya-umbiporang-untuk-ekspor), diakses 13 Januari 2020

Taufiqullah.2019. Mutu komoditas umbi-umbian, (Online), https://www.tneutron.net/pangan/mutukomoditas-umbi-umbian/., diakses 10 Januari 2020.

Team, honesdoct editorial. 2020. Glukomanan, Manfaat, Dosis, da Efek Samping. https://www.honestdocs.id/glukomanan. Diakses pada Sabtu, 11 januari 2020.

Ulfa dan Nafi'ah. 2018. Pengaruh Perendaman Nacl Terhadap Kadar Glukomanan Dan Kalsium Oksalat Tepung Iles-Iles (Amorphophallus Variabilis Bi), (Online), 2 (2): 124 (https://cjp.jurnal.stikescendekiautamakudus.ac.id/index.php/cjp/article/ view/27/27), diakses 21 Januari 2020.

Widari, N. Rasmito, A. 2018. Penurunan Kadar Kalsium Oksalat pada Umbi Porang (Amorphopallus Oncophillus) dengan Proses Pemanasan di dalam Larutan Nacl.Jurnal Teknik Kimia, (Online), 13 (1): 1, (http://www.ejournal.upnjatim.ac.id/index.php/tekkim/article/view/1144). Diakses 21 Januari 2020. 
Jurnal MEDFARM: Farmasi dan Kesehatan

Vol. 9, No.1, Januari 2020, hal 13-21

e-ISSN : 2715-9957 